\title{
KAIIAN KEKUATAN ASET DAN KONDISI KERENTANAN PENGHIDUPAN PETANI PADI SEBAGAI DAMPAK ALOKASI RUANG KOTA PADA KORIDOR JALAN HAMPARAN RAWANG
}

\author{
The Study of Rice Farmer Asset and Livelihood Vulnerability as Impact of \\ City Space Allocation Policy at the Hamparan Rawang Street Corridors
}

\section{Eki Asmindo Putra ${ }^{1}$ dan Iwan Rudiarto ${ }^{2}$}

\begin{abstract}
Abstrak: Rencana pembangunan kota difokuskan pada pembangunan fungsi perkotaan bukan pada kegiatan pertanian. Rencana ini diterjemahkan ke dalam kebijakan alokasi ruang kota. Kebijakan alokasi ruang kota menambah gesekan antara fungsi perkotaan dan pertanian yang berdampak pada kondisi penghidupan petani padi. Aset penghidupan terdiri dari aset manusia, keuangan, sosial, fisik dan alami. Kondisi keterpaparan, sensitivitas dan kemampuan adaptasi petani padi digunakan untuk menilai kondisi kerentanan penghidupan. Pendekatan penelitian kuantitatif digunakan dalam penelitian ini dengan penerapan teknik analisis deskriptif kuantitatif yang didukung oleh penerapan metode skoring dalam penentuan kekuatan aset dan kondisi penghidupan. Pengumpulan data dilakukan dengan observasi, wawancara dan penyebaran kuesioner. Hasil dari penelitian ini aset penghidupan petani padi berada pada kekuatan sedang dan penghidupan mereka berada dalam kondisi cukup rentan.
\end{abstract}

Kata Kunci: aset penghidupan, kerentanan penghidupan, keterpaparan, sensitivitas, kemampuan adaptasi, petani padi.

\begin{abstract}
City development plan focuses on enhancing urban functions rather than agricultural activities. This plan usually translated into space allocation of spatial management policy. However, this policy often arises the friction between the functions of urban and agriculture. It circumstance affects the livelihoods of rice farmers. Livelihood assets itself consist of assets of human, financial, social, physical, and natural. Conditions of exposure, sensitivity, and adaptive capacity used in this research to assess the livelihood vulnerability of rice farmers. The quantitative research approach that utilized in this study consists of quantitative descriptive analysis supported by the application of the scoring method to determine the strength conditions of livelihood assets and livelihood vulnerability. Data collection captured by observation, interviews, and questionnaires. Results of this study are of moderate strength to the livelihood assets of the farmers, and their livelihood is quite vulnerable.
\end{abstract}

Keywords: livelihood assets, livelihoods vulnerability, exposure, sensitivity, adaptive capacity, rice farmers.

\footnotetext{
${ }^{1}$ Badan Perencanaan Pembangunan (BAPPEDA) Provinsi Jambi

${ }^{2}$ Departeman Pembangunan Wilayah dan Kota Universitas Diponegoro Semarang
} 


\section{PENDAHULUAN}

Kota adalah wilayah administratif yang aktivitasnya dititikberatkan kepada aktivitas perkotaan bukan pada aktivitas pertanian. Mewujudkan definisi ini pemerintah kota menterjemahkan kebijakan pembangunan dalam bentuk kebijakan pengalokasi ruang kota. Sungai Penuh merupakan kota yang masih bercirikan pedesaan dilihat dari sebaran penduduk berdasarkan jenis mata pencaharian. Jumlah penduduk yang berprofesi sebagai petani diawal pembentukan kota sebesar $48.3 \%$.

Terjadinya perubahan penggunaan lahan di wilayah kota dapat disebabkan oleh faktor sosial, ekonomi dan kebijakan pemerintah. Aspek sosial yang berpengaruh terhadap perubahan guna lahan diantaranya adalah keberadaan hukum waris yang memaksa lahan terfragmentasi. Aspek ekonomi sangat erat kaitannya dengan teori bid-rent land yang menyebutkan nilai sebuah lahan berbanding terbalik dengan jarak lahan tersebut dari pusat kota. Hailu dan Brown (2007), dalam Sugianto dan Nugroho (2011) mengatakan bahwa kegagalan dalam beradaptasi terhadap perubahan dan pertumbuhan ruang perkotaan mempercepat proses konversi lahan. Tingginya nilai sewa tanah (land rent) yang diperoleh aktivitas sektor non-pertanian dibandingkan sektor pertanian serta rendahnya insentif untuk berusaha tani disebabkan oleh tingginya biaya produksi, sementara harga hasil pertanian relatif rendah mendorong terjadinya perubahan guna lahan. Selain itu, faktor kebutuhan keluarga petani yang terdesak oleh kebutuhan modal usaha atau keperluan keluarga lainnya (pendidikan, mencari pekerjaan non-pertanian, atau lainnya) seringkali membuat petani tidak mempunyai pilihan selain menjual sebagian lahan pertaniannya. Sedangkan aspek kebijakan pemerintah yang berpengaruh terhadap pola perubahan guna lahan adalah kebijakan alokasi ruang wilayah sebagaimana diamanatkan dalam dokumen RTRW kabupaten/kota.

Pemekaran wilayah sebagai salah satu upaya dalam pengembangan potensi lokal diharapkan mampu mengaselerasi peningkatan kesejahteraan masyarakat. Demikian juga dengan pengalokasian ruang kota dalam rencana makro pembangunan diupayakan untuk mengakomodir segala kekuatan dan peluang serta meminimalkan kelemahan dalam menghadapi tantangan yang dimiliki wilayah menuju pembangunan masyarakat yang berkeadilan. Kondisi diatas dituangkan dalam bentuk kebijakan pembangunan dan penataan ruang kota

Sebaran penduduk berdasarkan mata pencaharian pada awal dilakukan pemekaran terdiri atas $48.3 \%$ masyarakat bermata pencarian sebagai petani, $23.3 \%$ pedagang, $15.2 \%$ Pegawai Negeri Sipil (PNS) dan sisanya berprofesi sebagai buruh. Dominasi petani pada struktur penduduk menyebabkan pemerintah daerah dihadapkan pada dualisme konsep pembangunan, disatu sisi peningkatan kesejahteraan petani merupakan hal yang harus dipenuhi sedangkan disisi lain pembangunan kota ditujukan untuk perwujudan wilayah yang kegiatan utamanya bukan pertanian.

Sungai Penuh Dalam Angka menggambarkan terjadi peningkatan pertumbuhan penduduk dari tahun ke tahun. Peningkatan pertumbuhan penduduk dihadapkan kepada ketersedian lahan budidaya yang terbatas. Fenomena pergesekan fungsi ruang ini memunculkan pertanyaan besar yang harus dijawab yaitu "Bagaimanakah kondisi kekuatan aset dan kerentanan penghidupan petani sebagai dampak alokasi ruang kota di Koridor Jalan hamparan Rawang Kota Sungai Penuh?”. Pertanyaan ini dijawab dengan mengetahui dinamika perubahan guna lahan terkait kebijakan alokasi ruang kota sungai penuh serta kekuatan aset penghidupan petani padi yang mengerucut pada kondisi kerentanan penghidupan petani padi. 


\section{METODE PENELITIAN}

Tema penelitian ini digolongkan pada penelitian ekploratif dimana peneliti mencoba menggali fenomena yang terjadi di lokasi penelitian terkait tema perubahan guna lahan dan kerentanan penghidupan. Menurut Yunus, (2010), penelitian ekploratif dimulai dengan kemunculan kondisi yang sudah memberikan "clue" terhadap sasaran yang akan dicapai. Kondisi perubahan guna lahan menjadi pemukiman dan infrastruktur perkotaan menjadi clue dalam penentuan sasaran penelitian ini.

Penelitian ini menggunakan pendekatan penelitian kuantitatif, proses analisis menggunakan teknik deskriptif kuantitatif didukung oleh teknik skoring serta aplikasi Sistem Informasi Geografis ArcGIS dalam identifikasi perubahan guna lahan yang terjadi.

\section{a. Skoring}

Proses skoring dilakukan pada tahap awal analisis terhadap hasil kuisionel untuk menentukan kekuatan masing masing indikator penyusun variabel. Skoring terhadap indikator kekuatan aset dan kondisi kerentanan menggunakan nilai minimum 1 dan maksimum 3 untuk masing masing indikator.

Penentuan skor indikator dilakukan menggunakan persamaan berikut:

$$
\text { Skor } \mathbf{I}(\mathbf{x})=\frac{(\text { Total Skor } \mathbf{I}(\mathbf{x}))}{(\text { Jumlah Responden })} \ldots \ldots
$$

\section{b. Sistim Informasi Geografis ArcGIS}

Analisis perubahan guna lahan dilakukan untuk mendukung tema pergesekan ruang kota dengan aktivitas pertanian lahan basah. Menggunakan teknik Normalized Difference Built-up Index (NDBI) yang tersedia pada Software ArcGIS 10.2.2. Pemilihan teknik NDBI sebagai alat analisis disesuaikan dengan sasaran penelitian untuk melakukan klasifikas tutupan lahan yang terdiri atas kawasan terbangun (built-up area) dan tidak terbanguan (non built-up Area). NDBI di ukur berdasarkan persamaan berikut:

$$
\begin{aligned}
& \text { NDBI }=\frac{\text { MIR }- \text { NIR }}{\text { MIR }+ \text { NIR }}
\end{aligned}
$$

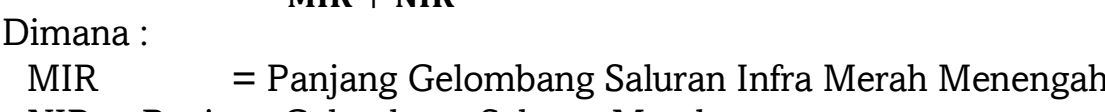

$$
\begin{aligned}
& \text { NIR }=\text { Panjang Gelombang Saluran Merah }
\end{aligned}
$$

Tutupan lahan yang dihasilkan kemudian ditumpangsusunkan dengan guna lahan hasil digitasi terhadap citra foto udara untuk mengetahui perubahan terhadap guna lahan sawah menjadi non sawah selama kurun waktu tahun 2007- 2015.

\section{c. Teknik Pengumpulan Data}

Pengumpulan data dilakukan menggunakan teknik observasi, wawancara tak terstruktur dan penyebaran kuisioner. Observasi dilakukan untuk melakukan pemetaan awal kondisi wilayah kajian. Wawancara ditujukan untuk mengetahui sebaran lahan garapan dalam bentuk kesatuan lahan garapan untuk mensfesifikkan wilayah kajian. Sebaran kuisioner ditujukan untuk mendapatkan data primer yang valid dan dapat dipercaya terkait kekuatan aset dan kondisi kerentanan. 


\section{Objek Penelitian}

Kota Sungai Penuh merupakan satu diantara dua kota administratif dan 10 kabupaten di Provinsi Jambi, Sumatera-Indonesia. Kota Sungai penuh terletak di sebelah Barat Provinsi Jambi dengan letak geografis pada 1010 14' 32" BT sampai dengan $101027^{\prime} 31^{\prime \prime}$ BT dan 020 01' 40" LS sampai dengan 020 14' 54" LS, dengan luas keseluruhan 39.150 Hektar. Kota Sungai Penuh terdiri dari 7 Kecamatan yaitu: Kecamatan Hamparan Rawang, Kota Baru, Kumun Debai, Pesisir Bukit, Pondok Tinggi, Sungai Penuh, Tanah Kampung seperti tampak pada Gambar 1 berikut :

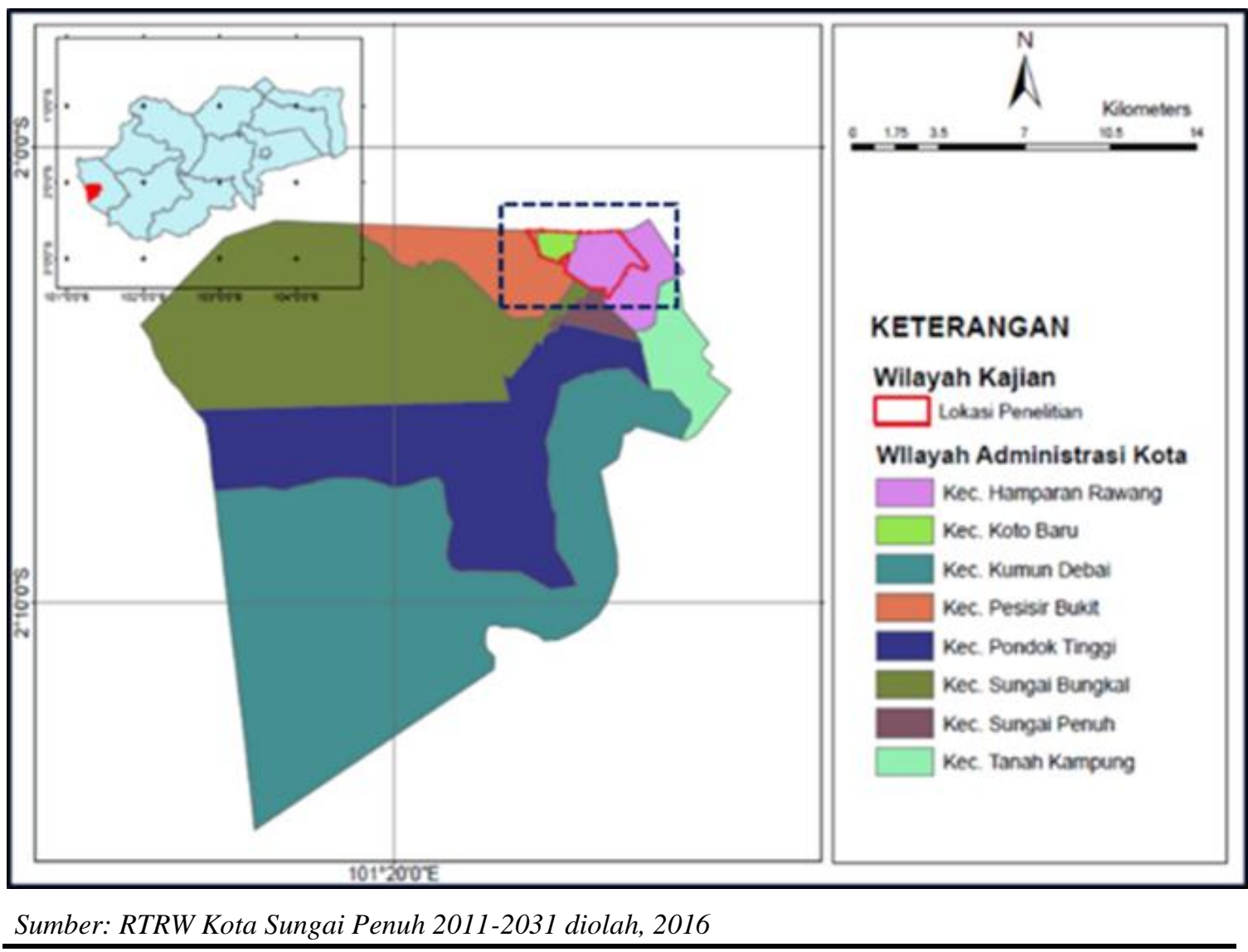

Gambar 1. Peta Administrasi Kota Sungai Penuh

Koridor Jalan Hamparan Rawang dipilih sebagai lokasi penelitian atas dasar pengamatan dan informasi data sekunder yang menyebutkan bahwa kawasan ini merupakan kawasan yang relatif cepat berkembang serta mengalamai perubahan guna lahan pertanian yang cukup signifikan diantara wilayah lainnya. Kondisi ini terlihat dari rata-rata kepemilikah lahan garapan di lokasi penelitian yang mengalami penurunan dari $0.45 \mathrm{Ha}$ menjadi $0.33 \mathrm{Ha}$ per rumah tangga petani padi (BPS Kota Sungai Penuh).

\section{ASET DAN KERENTANAN PENGHIDUPAN, KETERPAPARAN, SENSITIVITAS SERTA KEMAMPUAN ADAPTASI}

Fenomena perubahan guna lahan pertanian menjadi ruang kota akan berpengaruh terhadap kekuatan aset penghidupan (livelihood asset) dan kondisi kerentanan penghidupan (livelihood vulnerability) petani padi. Aset penghidupan petani terdiri atas lima komponen yaitu aset manusia, finansial, sosial, fisik dan alam. Tingginya pergesekan guna lahan 
menyebabkan petani padi terpapar (exposure) akan resiko kehilangan lahan garapan. Petani padi yang memiliki kemampuan beradaptasi (adaptive capacity) terhadap tekanan atau gangguan akan terjamin penghidupannya sedangkan yang tidak dapat bertahan akan berpotensi menjadi penduduk miskin perkotaan. Petani padi yang memiliki sensitivitas (sensitivity) tinggi terhadap tekanan atau gangguan yang dialami aset penghidupan mereka terancam jika tidak memiliki kemampuan beradaptasi. Kondisi keterpaparan, sensitivitas dan kemampauan adaptasi petani padi digunakan untuk merepresentasikan kondisi kerentanan penghidupan mereka.

\section{a. Kerentanan}

Intergovernmental Panel of Climate Change (IPCC), (2001) mendefinisikan kerentanan berkaitan dengan perubahan iklim dengan menghubungkan antara terminologi keterpaparan, kemampuan adaptive dan sensitivitas. Kerentanan merupakan kondisi sebuah sistem yang rentan atau tidak mampu mengatasi efek buruk dari peristiwa perubahan iklim dan variabilitas iklim lainnya. Menurut Turner, et al. (2003) dalam Metzger, et al., (2006). upaya penilaian kerentanan tidak hanya didasarkan atas pertimbangan perubahan iklim, tetapi juga didasarkan kepada tekanan-tekanan lain yang mungkin terjadi salah satunya tekanan berupa perubahan guna lahan.

Sejalan dengan pendapat diatas, Adger, (2006) menyatakan bahwa kerentanan adalah keadaan rawan sampai dengan berbahaya sebuah sistem yang diakibatkan oleh kondisi terpapar oleh tekanan yang terkait dengan perubahan lingkungan dan sosial sebagai akibat dari minimnya kapasitas untuk beradaptasi. Kerentanan juga berkaitan dengan kemampuan seseorang atau kelompok untuk mengantisipasi, menolak, mengatasi, dan pulih dari dampak bahaya alam atau buatan manusia. Salah satu keuntungan dari definisi ini adalah dapat diaplikasikan untuk mengidentifikasi kerentanan kelompok dan daerah dalam masyarakat.

\section{b. Keterpaparan}

Keterpaparan mengacu pada konsep Adger, (2006) yang mendefinisikan keterpaparan sebagai esensi dan sejauh mana aset secara alami dihadapkan dengan kondisi tekanan sosial ekonomi atau lingkungan. Keterpaparan mengacu pada tekanan yang disebabkan oleh perubahan frekuensi dari intensitas, besaran, frekuensi, durasi nyata dari sebuah bahaya dan sifat alami dari tekanan perubahan iklim maupun non-iklim. Konsep ini diperkuat Gulati dan Kelley (1999) dalam O'Brien et al., (2004) yang menyebutkan bahwa risiko perubahan guna lahan secara terstruktur sebagai akibat dari liberalisasi perdagangan dan kebijakan pengalokasian ruang terkait proses globalisasi merupakan sumber keterpaparan petani.

Dalam kontek penelitian ini, keterpaparan didefinisikan sebagai suatu kondisi dimana komunitas atau ekosistem dihadapkan pada kondisi bahaya sebagai akibat dari teknan sosial ekonomi maupun lingkungan. Keterpaparan disebabkan oleh perubahan guna lahan secara terstruktur ini diukur dengan mengetahui arahan pengguna lahan, jenis dan luasan perubahan lahan sawah, dampak perubahan guna lahan terhadap kepemilikan lahan garapan dan pendapatan serta ketersediaan tenaga kerja dibidang pertanian dimana besaran keterpaparan berbanding lurus dengan kondisi kerentana.

\section{c. Sensitivitas}

Sensitivitas mengacu pada konsepsi Adger, (2006) yang mendefinisikan sensitivitas sebagai sejauh mana seorang individu atau kelompok (dalam sebuah sistem) dipengaruhi oleh keterpaparan sebuah tekanan/perubahan baik iklim maupun non iklim. Konsep ini diperkuat oleh pendapat Luers, (2005) mendefinisikan sensitivitas sebagai sejauh mana suatu sistem akan merespon terhadap gangguan eksternal, dan juga termasuk dalam konsep kemampuan untuk menolak perubahan dan kemampuan untuk kembali ke kondisi 
sebelumnya. Kondisi dimana gangguan belum muncul dan belum menggangu sistem yang biasanya dilihat dari sisi keterkaitannya dengan ketahanan atau kapasitas mengatasi gangguan. Yesiana dan Yuniartanti, (2015) mengatakan bahwa sensitivitas sebuah komunitas dapat dilihat dari beberapa indikator, diantaranya: pendapatan tiap bulan, pengeluaran tiap bulan, kepemilikan aset dan akses modal/pinjaman usaha dimana besaran sensitivitas berbanding lurus dengan kondisi kerentanan.

\section{d. Kemampuan Adaptasi}

Kemampuan adaptasi merujuk pada konsep Fellman, (2012) yang menyebut sebuah sistem yang terpapar akan resiko dan sangat sensitif terhadap tekanan atau perubahan belum tentu dikategorikan kedalam sistem yang memiliki kerentanan. Alasannya adalah kapasitas sebuah sistem untuk beradaptasi terhadap tekanan tidak dapat dijelaskan hanya oleh keterpaparan dan sensitivitas. Kerentanan itu sendiri merupakan adalah dampak bersih yang terus berlansung setelah mempertimbangkan kondisi kemampuan adaptasi sebuah sistem. Konsep ini diperkuat oleh pendapat Gallopin, 2006 yang menyebutkan bahwa kondisi kerentanan dipengaruhi oleh kemampuan beradaptasi terhadap keterpaparan dan sensitivitas sebuah sitem.

Luers, et al., (2003) mendefinisikan kemampuan beradaptasi sebagai kemampuan sebuah sistim untuk dapat memodifikasi kondisinya saat ini untuk menurunkan tingkat kerentanan yang dimiliki oleh sistem dimaksud. Deressa, et al., (2008) mengatakan bahwa kemampuan beradaptasi petani direpresentasikan oleh nilai kekayaan, penguasaan teknologi, ketersediaan infrastruktur dan sistemnya, potensi irigasi, dan tingkat pengetahuan petani dimana besaran kemampuan adaptasi berbanding terbalik dengan kondisi kerentanan.

\section{e. Penghidupan}

Chamber dan Conway (1991) menyebutkan penghidupan manusia terdiri atas kemampuan dan ketersediaan sarana pemenuhan kehidupan mereka termasuk makanan, pendapatan dan aset. Aset terdiri atas aset berwujud dan aset yang tak berwujud. Aset berwujud dapat berupa sumberdaya dan tabungan sedangkan aset tak berwujut berupa klaim dan akses terhadap sumberdaya. Scooness (1998) menyebutkan bahwa penghidupan individu atau rumah tangga terdiri dari kemampuan, aset dan kegiatan yang dibutuhkan dalam pemenuhan kebutuhan hidup. Aset dalam pengertian penghidupan ini dikategorikan menjadi lima jenis aset yang berbeda yaitu: aset alam, fisik, manusia, finansial dan sosial. Penelitian kali ini membatasi definisi kekuatan aset sebagai kekuatan yang disusun oleh lima aset penghidupan sebagaimana yang didefinisikan oleh Scooness (1998).

\section{f. Kerentanan Penghidupan}

Kerentanan penghidupan mengacu pada konsepsi kerentanan menurut Leichenko dan O'Brien, (2001). Menurut mereka kerentanan adalah kondisi sejauh mana perubahan lingkungan dan ekonomi mempengaruhi kapasitas suatu daerah, sektor, ekosistem, dan kelompok-kelompok sosial untuk menanggapi berbagai jenis guncangan alam dan sosial ekonomi. Kerentanan dinamis ini menggabungkan pemikiran tradisional tentang kerentanan dengan memunculkan tiga komponen utama yang mempengaruhi kondisi kerentanan, yaitu: keterpaparan, sensitivitas dan kapasitas adaptasi, dengan menempatkan konsep-konsep ini kedalam konteks sosial ekonomi dan lingkungan yang berubah dengan cepat.

Chamber dan Conway, (1991) mengatakan bahwa penghidupan akan berlangsung terus menerus ketika sistem penghidupan dapat mengatasi dan memulihkan diri dari tekanan dan gangguan serta dapat mempertahankan atau meningkatkan kemampuan serta aset yang dimiliki baik sekarang maupun dimasa depan, dengan tidak menghabiskan sumber daya 
alam yang dimiliki. Sedangkan kerentanan penghidupan akan terjadi apabila sebuah sistem gagal atau tidak mampu pulih dari tekanan atau gangguan yang dialaminya.

Nazari, et al., (2015) menyebutkan bahwa perubahan terhadap sistem penghidupan dipicu oleh berbagai aspek yang bila disederhanakan dibedakan menjadi 2 aspek utama yaitu lingkungan dan sosial ekonomi. Penelitian ini difokuskan pada aspek sosial ekonomi petani padi seperti konsep yang dikembangkan Nazari diatas.

Kondisi kerentanan penghidupan dinilai berdasarkan hubungan antara kondisi variabel yang besarannya berbanding lurus dengan kondisi kerentanan dibagi dengan variabel yang besarannya berbanding terbalik dengan kondisi kerentanan. Dalam bentuk persamaan dapat dilihat pada persamaan 6 berikut:

$$
\text { Skor Kerentanan }=\frac{\text { Skor Keterpaparan }+ \text { Skor Sensitivitas }}{\text { Skor Kemampuan Adaptasi }} \ldots \ldots \ldots \text { persamaaan }(3)
$$

\section{PEMBAHASAN}

a. Perubahan Guna Lahan

Analisis tutupan lahan menggunakan teknik NDBI yang dikembangkan oleh Zha, et al. (2003) dalam Hanqiu, (2007). Klasifikasi tutupan lahan berdasarkan teknik ini menggunakan Band 7 LANSAT 7 USGS sebagai Band Moderate Infra Red (MIR) dan band 4 sebagai Band Near Infra Red (NIR). Menggunakan aplikasi ArcGIS 10.2.2 dihasilkan klasifikasi tutupan lahan wilayah kajian seluas 642.87 Hektar atau 90.2\% merupakan lahan garapan berupa sawah dan sisanya 69.57 Hektar atau 9.77\% merupakan lahan terbangun seperti tampak pada Gambar 2 berikut:

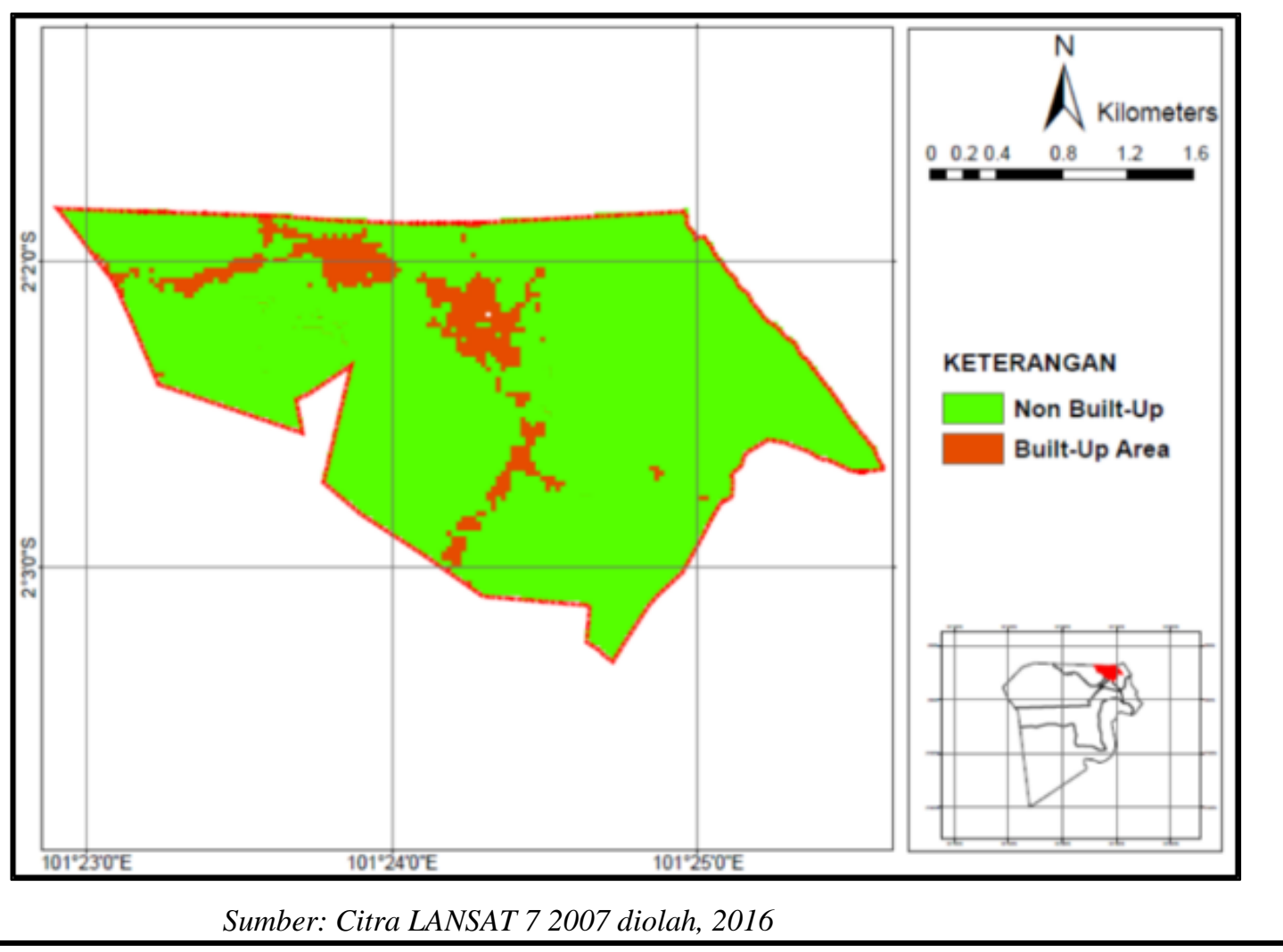

Gambar 2. Tutupan Lahan Tahun 2007 
Analisis terhadap perubahan luasan guna lahan dilakukan dengan melakukan overlay terhadap tutupan lahan dengan peta digitasi guna lahan citra foto udara tahun 2015. Hasil overlay terhadap kedua layer diatas menghasilkan perubahan guna lahan yang terjadi selama kurun waktu pemekaran sampai dengan tahun 2015. Perubahan tersebut memberi gambaran terjadi perubahan luasan guna lahan sawah sebesar $81.99 \mathrm{Ha}$ atau sebesar 12.75 $\%$ dari luas sawah tahun 2007 seperti terlihat pada Gambar 3 berikut:

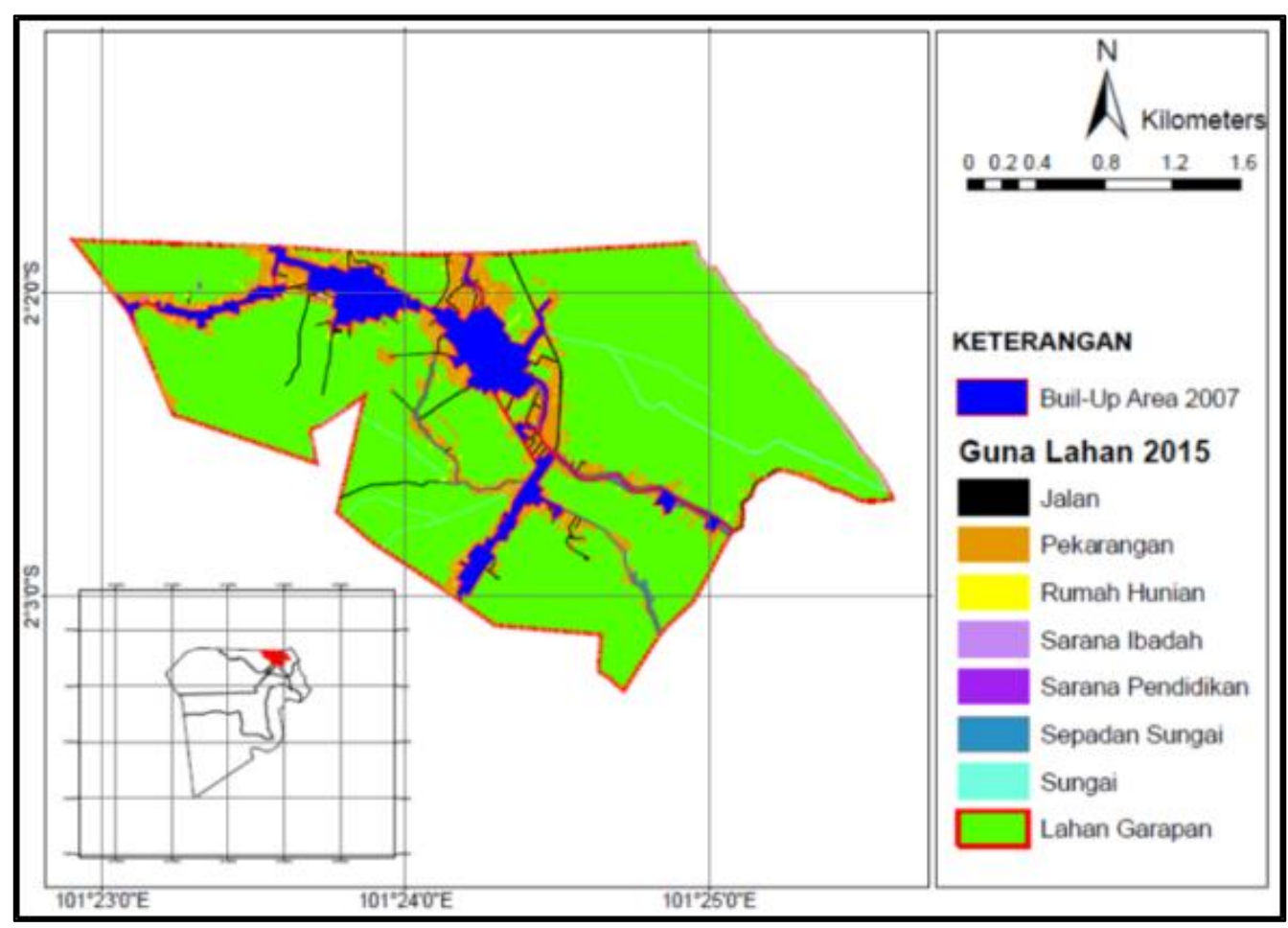

Sumber: Citra LANSAT 72007 diolah, 2016

Gambar 3. Perubahan Guna Lahan Kurun Waktu 2007-2015

Perubahan guna lahan yang terjadi didominasi oleh guna lahan pemukiman yang terdiri atas guna lahan rumah hunian sebesar $20.06 \%$ dan pekarangan sebesar $73.31 \%$. Guna lahan juga berubah menjadi jalan dengan luasan sebesar $4.76 \%$ dan terakhir guna lahan berubah menjadi sarana ibadah dan sarana pendidikan sebesar $0.15 \%$.

\section{b. Kekuatan Aset Penghidupan}

Pengolahan data kuisioner menghasilkan gambaran tentang kekuatan aset penghidupan petani padi berada pada kekuatan "sedang". Kekuatan aset penghidupan ditampilkan dalam bentuk tabel kekuatan aset dan pembobotan serta polygon aset penghidupan seperti tampak pada Tabel 1 berikut:

Kekuatan aset masing variabel diplotkan kedalam poligon aset penghidupan seperti tampak pada Gambar 4. Kekuatan aset penghidupan pada kondisi sedang dibangun oleh kekuatan aset manusia pada kekuatan tinngi dan empat komponen pembangun kekuatan aset lainnya berada pada kekuatan sedang. Aset manusia berada pada kekuatan tinggi dibangun oleh kekuatan indikator rasio ketergantungan, kemampuan bertani dan anggota keluarga berjenis kelamin perempuan yang memiliki skor diatas nilai tengah. Sedangkan 
indikator tingkat pendidikan dan ukuran keluarga memberikan dampak pengurangan terhadap kekuatan aset.

Tabel 1. Kondisi Skor Dan Bobot Aset Penghidupan

\begin{tabular}{|c|c|c|c|c|c|c|c|}
\hline \multicolumn{5}{|c|}{ Skor Aset Penghidupan } & \multirow[b]{2}{*}{$\begin{array}{l}\text { Skor } \\
\text { Total }\end{array}$} & \multirow{2}{*}{$\begin{array}{c}\text { Kelas Klasifikasi } \\
\text { Kekuatan } \\
\text { Variabel Aset }\end{array}$} & \multirow{2}{*}{$\begin{array}{c}\text { Kekuatan } \\
\text { Aset } \\
\text { Penghidupan }\end{array}$} \\
\hline $\begin{array}{c}\text { Aset } \\
\text { Manusia }\end{array}$ & $\begin{array}{c}\text { Aset } \\
\text { Finasial }\end{array}$ & $\begin{array}{c}\text { Aset } \\
\text { Sosial }\end{array}$ & Aset Fisik & As et Alam & & & \\
\hline 11.89 & 8.55 & 8.84 & 10.78 & 8.59 & 48.65 & . $25.00-41.67$ & $\begin{array}{l}\text { Rendah } \\
\text { Sedang }\end{array}$ \\
\hline & & & & & & $58.34-75.00$ & Tinggi \\
\hline
\end{tabular}

Sumber: Survey primer diolah, 2016

\section{Kondisi Poligon Aset Penghidupan Petani Padi Jalan Hamparan Rawang}

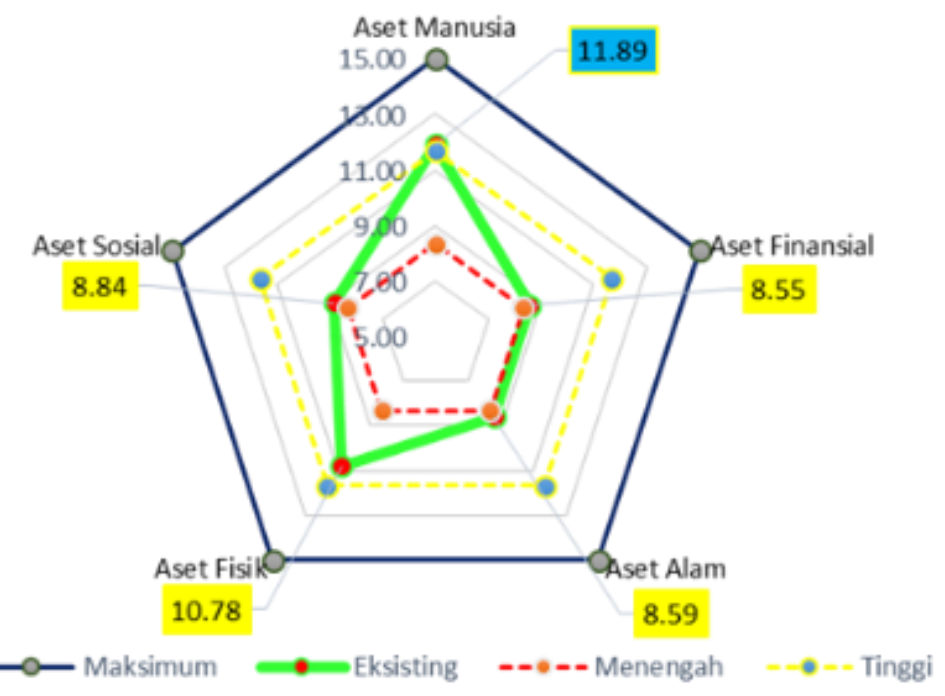

Sumber: Survey primer 2016, diolah

Gambar 4. Poligon Aset Penghidupan

Kekuatan aset penghidupan pada kondisi sedang dibangun oleh kekuatan aset manusia pada kekuatan tinngi dan empat komponen pembangun kekuatan aset lainnya berada pada kekuatan sedang. Aset manusia berada pada kekuatan tinggi dibangun oleh kekuatan indikator rasio ketergantungan, kemampuan bertani dan anggota keluarga berjenis kelamin perempuan yang memiliki skor diatas nilai tengah. Sedangkan indikator tingkat pendidikan dan ukuran keluarga memberikan dampak pengurangan terhadap kekuatan aset.

Aset fisik berada pada kekuatan sedang, kondisi ini dibangun oleh kekuatan indikator ketersediaan fasilitas dan akses pendidikan serta kesehatan, status kepemilikan tempat tinggal, kualitas jalan yang memiliki skor diatas nilai tengah. Sedangkan indikator kepemilikan modal dan kualitas irigasi memberikan dampak pengurangan terhadap 
kekuatan aset. Aset sosial berada pada kekuatan sedang. Empat indikator yaitu kepedulian pemerintah, kepesertaan kelompok tani, akses terhadap bantuan serta frekwensi penerimaan waskat memiliki skor dibawah nilai tengah. hanya indikator akses terhadap pasar yang memiliki skor diatas nilai tengah. Aset alam berada pada kekuatan sedang, kondisi kekuatan sedang ini dibangun oleh skor seluruh indikator berada dibawah nilai tengah. Aset alam adalah aset paling sulit untuk diintervensi, karena nilainya merupakan kondisi alamiah yang tersedia.

Aset Finansial berada pada kekuatan sedang dan merupakan komponen dengan kekuatan paling lemah diantara lima komponen aset penghidupan. Kondisi ini dibangun oleh skor empat indikator penyusun kekuatan aset yaitu pendapatan bulanan, luasan lahan garapan tiap tahunnya, jumlah dan kepemilikan tabungan serta pengeluaran bulanan berada dibawah nilai tengah. Hanya indikator kepemilikan mata pencaharian lain yang meberikan penguatan terhadap kekuatan aset finansial. Kekuatan aset diurutkan dari kekuatan tertinggi sampai terendah serta kekuatan masing masing indikator pembangunnya ditampilkan pada Gambar 5 berikut:

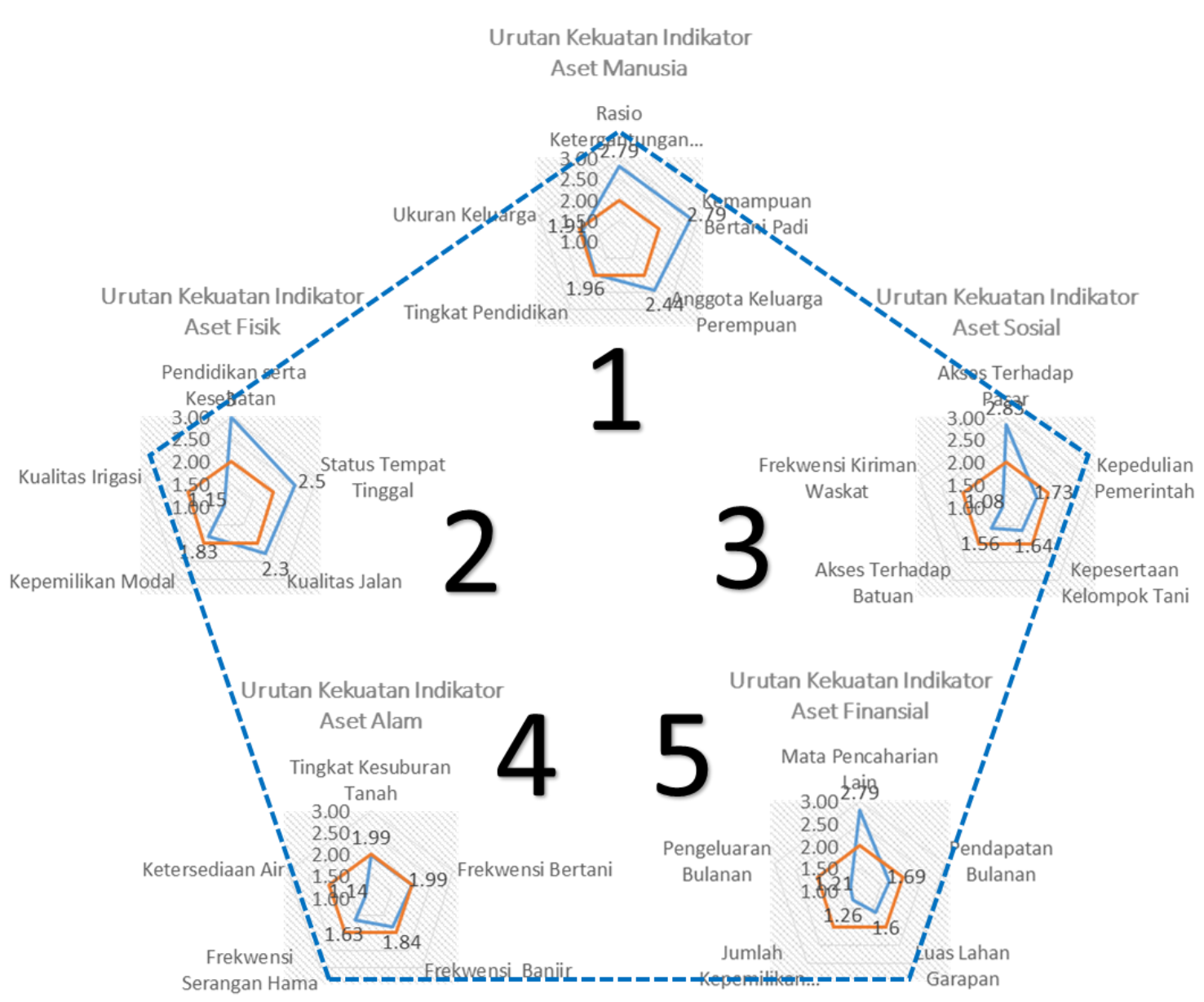

Sumber: Survey primer diolah, 2016

Gambar 5. Kekuatan Indikator Pembangun Aset Penghidupan 


\section{c. Kondisi Keterpaparan}

Kondisi keterpaparan sedang diperoleh dari kondisi indikator kemampuan pendapatan bertani dalam memenuhi kebutuhan hidup sehari-hari, kepemilikan luas lahan garapan umumnya hanya seluas 0.6 Hektar setahun masih sangat jauh dari luas minimal pengolahan lahan garapan yang dapat mensejahterakan petani. Tingkat kepedulian pemerintah yang masih rendah menyumbang keterpaparan tinggi bagi petani. Indikator yang memiliki skor diatas nilai tengah memberikan penguatan terhadap kondisi keterpaparan. Indikator faktor pengurangan luas lahan garapan oleh keberadaan sistim waris serta masih berlimpahnya ketersediaan buruh tani memiliki skor dibawah nilai tengah sehingga memberikan dampak pengurangan kondisi keterpaparan.

Sejalan dengan temuan Boori, et al., (2015) bahwa urbanisasi memiliki dampak negatif terhadap perubahan penggunaan lahan. Hilangnya keanekaragaman hayati, fragmentasi habitat dan penurunan kemampuan layanan sumberdaya menjadi penyebab utama peningkatan keterpaparan sistem. Perubahan guna lahan menjadi pemukiman dan areal komersil mengarah ke proses transformasi sosial-ekonomi. Sistem pertanian tradisional menjadi runtuh, tapi memunculkan sistem baru yang berorientasi pada industri dan perdagangan diwilayah yang mulai berkembang. Kondisi ini menyebabkan sistem menjadi rentan. Kekuatan indikator-indikator pembangun kondisi keterpaparan terlihat pada Gambar 6 berikut:

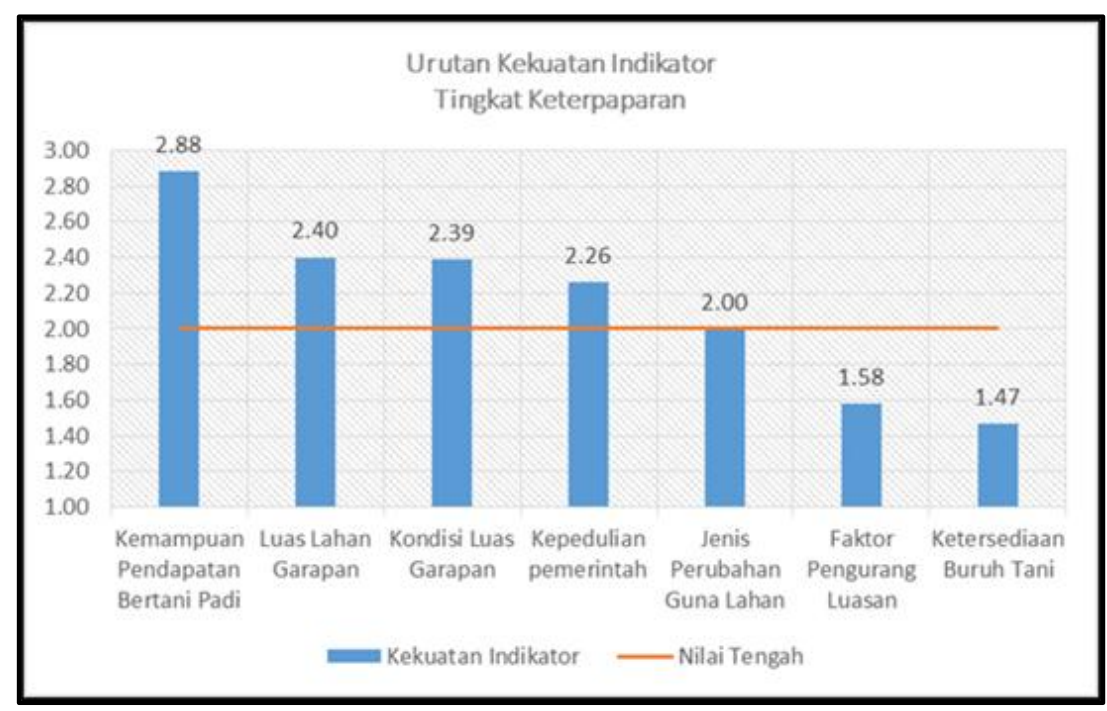

Sumber: Survey primer diolah, 2016

\section{Gambar 6. Kondisi Indikator Keterpaparan}

\section{d. Kondisi Sensitivitas}

Kondisi sensitivitas sedang diperoleh dari kondisi indikator pengeluaran petani padi yang tidak dapat dicukupi oleh pandapatan bertani, akses terhadap bantuan sangat rendah, pendapatan bertani yang rendah akibat penguasaan lahan yang sangat kecil, kepemilikan modal sarana komunikasi dan informasi, ukuran keluarga umumnya berjumlah lebih dari 45 orang menambah beban pendapatan dalam pemenuhan kebutuhan, serta tingkat pendidikan pada tingkat sekolah menengah pertama menyebabkan petani padi miskin kreativitas dan inovasi dalam upaya pemenuhan penghidupan. Kondisi sensitivitas ini 
diturunkan oleh non-angkatan kerja sebanyak 1-2 orang yang merepresentasikan rendahnya rasio ketergantungan dalam keluarga.

Kondisi diatas sejalan dengan temuan Gebrehiwot dan Anne, (2013) yang menyebutkan akses petani terhadap kredit memiliki dampak positif pada kemungkinan untuk beradaptasi terhadap tekanan. Meningkatkan akses petani terhadap kredit memungkinan petani untuk melakukan investasi produktif sebagai upaya pemenuhan penghidupan mereka. Kondisi ini diperkuat oleh Ariti, et al., (2015) bahwa kemampuan adaptasi terhadap perubahan guna lahan didukung oleh tingkat pendidikan dan pengalaman dalam mengelola sumberdaya penghidupan dan sebaliknya kemampuan adaptasi akan terhambat oleh kemampuan finansial yang rendah. Kekuatan indikator-indikator pembangun kondisi sensitivitas terlihat pada Gambar 7 berikut:

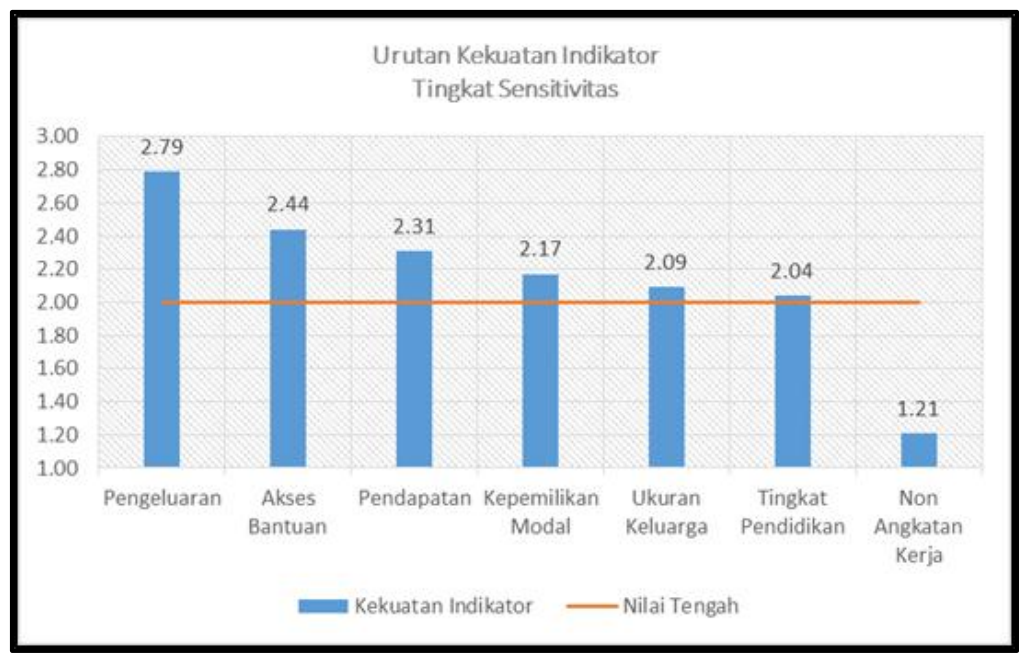

Sumber: Survey primer diolah, 2016

Gambar 7. Kondisi Indikator Sensitivitas

e. Kondisi Kemampuan Adaptasi

Kemampuan adaptasi sedang diperoleh dari kondisi Indikator kemampuan adaptasi yang memiliki skor dibawah nilai tengah yaitu frekwensi bertani dua kali dalam setahun masih dapat ditingkatkan menjadi 2.5-3 (IP 250-300) dengan aplikasi pengetahuan dan teknologi pertanian, tetap memilih bertani sambil mencari alternatif penghasilan lain sebagai preferensi dimasa depan, upaya mencari alternatif lahan garapan dengan sistim sewa untuk menambah luasan lahan garapan, rendahnya penguasaan teknologi akibat rendahnya tingkat partisipasi dalam kelompok tani menurunkan kemampuan meningkatkan produktivitas dan terakhir kemampuan menabung petani yang sangat rendah dilihat dari umumnya petani miliki tabungan dibawah satu juta bahkan tidak menabung sama sekali. Indikator pengetahuan bertani yang umumnya sudah bertani lebih dari 20 tahun serta keberadaan mata pencaharian selain bertani bergerak dibidang perdagangan dan jasa memiliki skor diatas nilai tengah memberikan penguatan terhadap kondisi kemampuan adaptasi.Kekuatan indikator-indikator pembangun kondisi kemampuan beradaptasi terlihat pada Gambar 8 berikut: 


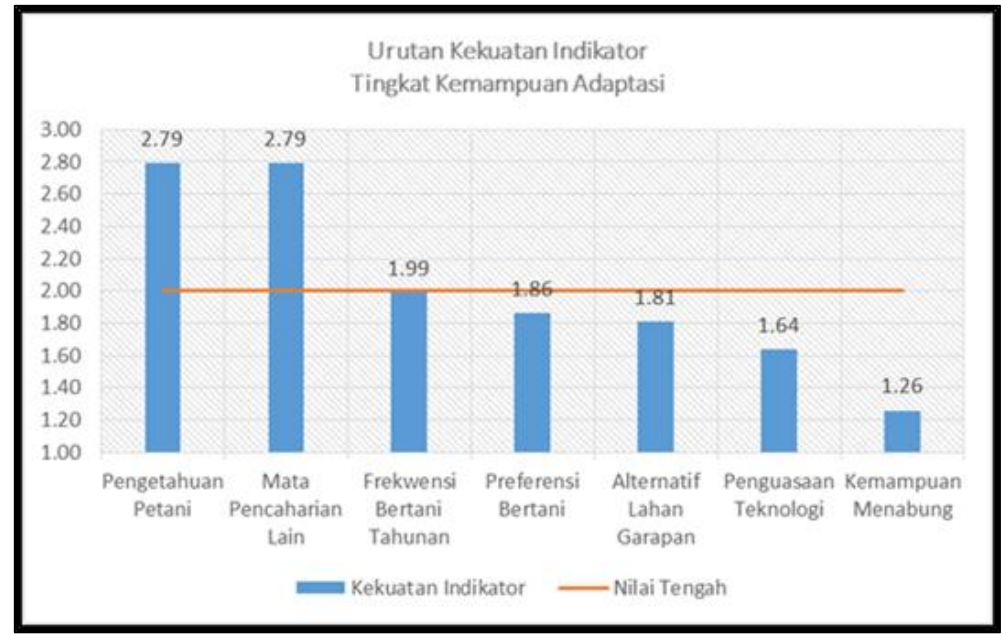

Sumber: Survey primer diolah, 2016

Gambar 8. Kekuatan Indikator Kemampuan Adaptasi

Sejalan dengan apa yang ditemukan oleh Ariti, et al., (2015) bahwa kemampuan adaptasi terhadap perubahan guna lahan didukung oleh tingkat pendidikan dan pengalaman dalam mengelola sumberdaya penghidupan. Sebaliknya kemampuan adaptasi akan terhambat oleh kemampuan finansial yang rendah, minimnya informasi dan serta rendahnya tingkat penguasaan teknologi terkait pengelolaan sumberdaya penghidupan yang berkesesuaian dengan kondisi dilokasi penelitian.

\section{f. Kondisi Kerentanan Penghidupan}

Penghidupan petani berada pada kondisi "cukup rentan”. Kondisi ini dibangun oleh kondisi keterpaparan, sensitivitas dan kemampuan adaptasi semuanya pada kondisi sedang. Kondisi variabel kerentanan penghidupan terlihat pada tabel 2 berikut ini:

Tabel 2. Kondisi Variabel Kerentanan Penghidupan

\begin{tabular}{|c|c|c|c|c|c|}
\hline \multicolumn{3}{|c|}{ Skor Variabel Kerentanan Penghidupan } & \multirow{3}{*}{$\begin{array}{c}\text { Skor } \\
\text { Kerentanan }\end{array}$} & \multirow{3}{*}{$\begin{array}{c}\text { Bobot } \\
\text { Kerentanan }\end{array}$} & \multirow{3}{*}{$\begin{array}{c}\text { Kondisi } \\
\text { Kerentanan } \\
\text { Penghidupan }\end{array}$} \\
\hline Keterpaparan & Sensitivitas & $\begin{array}{c}\text { Kemampuan } \\
\text { Adaptasi }\end{array}$ & & & \\
\hline 1 & 2 & 3 & & & \\
\hline \multirow{4}{*}{14.98} & \multirow{4}{*}{15.05} & \multirow{4}{*}{14.14} & \multirow{4}{*}{2.12} & $0.67-2.00$ & Tidak Rentan \\
\hline & & & & $2.01-3.33$ & Cukup Rentan \\
\hline & & & & $3.34-4.67$ & Rentan \\
\hline & & & & $4.68-6.00$ & Sangat Rentan \\
\hline
\end{tabular}

Sumber: Survey primer diolah, 2016

Cukup rentannya kondisi penghidupan disebabkan oleh kondisi keterpaparan dan sensitivitas belum mampu diimbangi sepenuhnya oleh kemampuan adaptasi. Kondisi keterpaparan penyumbang kerentanan pada saat ini masih didominasi oleh kondisi fragmentasi lahan garapan akibat sistim waris dan belum didominasi oleh dampak kebijakan alokasi ruang kota. Masih rendahnya perhatian pemerintah dalam upaya menggeser sumber penghidupan dari sektor produksi pertanian menjadi sektor jasa dan agribisnis menambah kondisi kerentanan. Transformasi guna lahan menjadi penggunaan lahan perkotaan belum 
mampu membangkitkan sumber-sumber penghidupan baru bagi masyarakat. Rendahnya tingkat pendidikan dan besarnya ukuran keluarga serta rendahnya kemampuan finansial menjadikan petani padi menjadi lebih sensitif terhadap tekanan dan gangguan yang dialami. Kemampuan adaptasi dengan bekerja disektor jasa dan perdagangan belum optimal keberadaannya dalam mengimbangi kondisi keterpaparan dan sensitivitas yang dimiliki. Kurang optimalnya kemampuan adaptasi ini salah satunya disumbang oleh belum adanya kelembagaan formal pembangun kekuatan aset sosial yang memayungi upaya adaptasi petani padi.

Sejalan dengan temuan Boori, et al., (2015) yang menyatakan bahwa perubahan guna lahan menjadi pemukiman dan areal komersil mengarah ke proses transformasi sosialekonomi. Sistem pertanian tradisional menjadi runtuh, tapi memunculkan sistem baru yang berorientasi pada industri dan perdagangan diwilayah yang mulai berkembang. Kondisi ini menyebabkan sistem menjadi rentan, dengan kata lain penggunaan lahan dengan tipologi ini mengalami kehilangan terlalu banyak dan mendapatkan terlalu sedikit dari sebuah proses pembangunan.

\section{KESIMPULAN}

Penghidupan petani padi berada pada kondisi "cukup rentan", kondisi ini diperoleh pada kondisi kekuatan aset penghidupan "sedang". Kondisi cukup rentan diartikan sebagai kondisi dimana penghidupan petani padi mengalami tekanan dan gangguan namun tekanan dan gangguan dimaksud belum sepenuhnya disebabkan oleh kebijakan alokasi ruang. Kondisi cukup rentan dibangun oleh kondisi tingkat keterpaparan dan sensitivitas pada kondisi sedang disisi lain kemampuan adaptasi belum mampu mengimbangi keterpaparan dan sensitivitas yang dimiliki.

Kondisi keterpaparan sedang disumbang oleh kepemilikan lahan garapan yang sangat kecil sehingga penghasilan bertani padi tidak mampu mencukupi kebutuhan hidup seharihari. Kepemilikan lahan yang kecil mengalami tekanan berupa pengurangan luas lahan garapan akibat sistim waris, kebutuhan ruang pemukiman serta ruang untuk sarpras perkotaan sebagaimana diperlihatkan analisis perubahan guna lahan yang menghasilkan $12.75 \%$ lahan sawah terkonversi selama kurun waktu pemekaran sampai tahun 2015. Keterpaparan tinggi disumbang juga oleh rendahnya kepedulian pemerintah terkait peningkatan kesejahteraan petani padi disebabkan ketidak mampuan anggaran menyasar upaya peningkatan produktivitas pertanian akibat terbentur dengan rencana pembanguanan dan pengalokasian kota. Kondisi keterpaparan tinggi tidak disumbang oleh ketersediaan buruh tani karena profesi buruh tani merupakan salah satu upaya adaptasi petani dalam memenuhi kebutuhan hidup mereka.

Kondisi sensitivitas sedang dibangun oleh kondisi tingginya pengeluaran yang tidak diimbangi kemampuan pendapatan bertani padi untuk memenuhinya serta. Tingginya pengeluaran juga disumbang oleh ukuran keluarga yang besar dengan kepala keluarga berpendidikan maksimal sampai tingkat sekolah menengah pertama. Rendahnya tingkat pendidikan menyebabkan kepala keluarga menjadi kurang bisa beradaptasi terhadap tekanan dan gangguan kondisi ini diperburuk dengan rendahnya kepemilikan modal fisik sebagai alat bantu beradaptasi petani padi

Kondisi kemampuan adpatasi sedang dibangun oleh dominannya petani yang tetap menggantungkan pemenuhan penghidupan pada ketersediaan sumberdaya lahan sambil mencari sumber penghidupan lain. Keberadaan penghasilan selain bertani dibidang jasa dan perdagangan belum diperkuat oleh keberadaan kelembagaan yang memadai. Kemampuan finansial tidak mampu meningkatkan produktifitas pertanian karena keterbatasan kondisi fisik lahan garapan. Upaya adaptasi dengan penerapan teknologi terkendala oleh rendahnya 
penguasaan teknologi pertanian akibat kepedulian pemerintah dan kepesertaan dalam kelompok tani yang rendah.

Perbaikan terhadap kondisi kerentanan penghidupan dilakukan paralel dengan melakukan intervensi terhadap kekuatan aset penghidupan dengan menyasar indikator penyusun kekuatan aset penghidupan. Indikator yang disasar adalah indikator yang memiliki kekuatan sedang menuju rendah dengan jenis intervensi berkesesuaian dengan tipologi sebuah kota.

\section{DAFTAR PUSTAKA}

Adger, (2006). Vulnerability, Global Environment Change, Volume 16, pp 268-281. http://doi.org/10.1016/j.gloenvcha.2006.02.006

Ariti, A,T., Vlieta, J. Verburga P,H., (2015). Land-use and land-cover changes in the Central Rift Valley of Ethiopia: Assessment of perception and adaptation of stakeholders, Applied Geography Volume 65, pp 28-37. http://doi.org/10.1016/j.apgeog.2015.10.002

Boori, M.S, Vozenilek1, V, Choudhary1, K (2015). Exposer Intensity, Vulnerability Index And Landscape Change Assessment In Olomouc, Czech Republic, The International Archives of the Photogrammetry, Remote Sensing and Spatial Information Sciences, Volume XL-7/W3, Berlin, Germany. http://doi.org/10.5194/isprsarchives-XL-7-W3-771-2015

Chambers, R., dan Conway G,R., (1991). Sustainable Rural Livelihoods: Practical Concepts for the 21st Century, IDS Discussion Paper 296. Institute of Development Studies, Brighton.

Deressa, T., Hassan, R.M., Ringler, C., (2008). Measuring Ethiopian Farmers' Vulnerability to Climate Change Across Regional States. International Food Policy Research Institute (IFPRI) Discussion Paper, No. 00806

Fellmann, T., (2012). The assessment of climate change-related vulnerability in the agricultural sector: reviewing conceptual frameworks. In: Proceedings of a Joint FAO/OECD Workshop on building resilience for adaptation to climate change in the agriculture sector, Rome, Italy, 23-24 April, 2012, pp. 37-61 http://www.fao.org/docrep/017/i3084e/i3084e.pdf

Gallopin, G.C., (2006). Linkages between vulnerability , resilience , and adaptive capacity, Global Environment Change Volume 16, pp. 293-303. http://doi.org/10.1016/j.gloenvcha.2006.02.004

Gebrehiwot, T,, dan Veen, A., (2013). Farm Level Adaptation to Climate Change: The Case of Farmer's in the Ethiopian Highlands, Environmental Management, volume 52. Pp 29-44 http://doi 10.1007/s00267013-0039-3

Hanqiu, X. (2007). Extraction of Urban Built-up Land Features from Lansat Imagery Using a Thematic-Orinted Index Combination Technique. Photogrammetric Engineering and Remote Sensing Vol. 73 No. 12, pp.1381-1391

Kota Sungai Penuh Dalam Angka tahun (2015). Kantor Badan Pusat Statistik Kota Sungai Penuh, 2015.

Leichenko, R.M., dan O'Brien K.L. (2001). The dynamics of rural vulnerability to global change: the case of southern africa, Mitigation and Adaptation Strategies For Climate Change, 1-18 http://doi: 10.1023/A:1015860421954

Metzger, M. J., Rounsevell, M. D. A., \& Acosta-michlik, L., (2006). The vulnerability of ecosystem services to land use change, Agriculture, Ecosystems \& Environment, volume 114, 69-85. http://doi.org/10.1016/j.agee.2005.11.025

Nazari, S., Pezeshki, G., Sedighi, H., \& Azadi, H,. (2015). Vulnerability of wheat farmers : Toward a conceptual framework. Ecological Indicators volume 52, 517-532. http://doi.org/10.1016/j.ecolind.2015.01.006

O’Brien, K., Leichenko, R., Kelkar, U., Venema, H., Aandahl, G., Tompkins, H., West, J., (2004). Mapping vulnerability to multiple stressors: climate change and globalization in India, 14, 303-313. http://doi.org/10.1016/j.gloenvcha.2004.01.001

Rencana Tata Ruang Wilayah Kota Sungai Penuh Tahun 2011-2031. Badan Perencanaan Pembangunan Kota Sungai Penuh. 2012.

Scoones, I, (1998). Sustainable Rural Livelihoods: Framework for Analysis. IDS Working Paper 72. Sussex: ID

Sugiyanto dan Nugroho, 2011. Konversi Lahan dan Pilihan Petani. http://mpra.ub.uni-muenchen.de/28753/. Diunduh tanggal 14 Maret 2016

Turner, B. L., Kasperson, R. E., Matson, P. A., Mccarthy, J. J., Corell, R. W., Christensen, L., .. Schiller, A. (2003). A framework for vulnerability analysis in sustainability science, 100(14).

Yunus, M.S. 2010. Metode Penelitian: Wilayah Kontemporer. Cetakan 1st . Pustaka Pelajar. Yogyakarta 